\title{
Conceiving the Multitude: Eighteenth-Century Popular Riots and the Modern Language of Social Disorder
}

\author{
PAB L O SÁNCHEZ LEÓN \\ Departamento de Derecho Constitucional e Historia del \\ Pensamiento y de los Movimientos Sociales y Políticos, Universidad \\ del País Vasco \\ E-mail: psleon@gmail.com
}

SUMmARY: The image of the crowd as an irrational, spontaneous multitude is commonly related to the works of a first generation of social psychologists writing in the early twentieth century, yet its basic features can be found in conceptual innovations developed as early as the Enlightenment. This article focuses on a particular protest in eighteenth-century Spain in order to reflect on the transformation in the meaning of essential terms which occurred in the semantic field of disorder. The so-called motin de Esquilache of 1766 forced the authorities to renew their discourse in order to deprive the movement of legitimacy, fostering semantic innovation. The redefinition of riot implied a process of conceptualization that not only stressed the protagonism of the disenfranchized but also altered a long-established tradition that linked riots to conspiracies and devised a new anthropology depicting the populace as a subject unable to produce ideas on its own.

\section{INTRODUCTION}

For decades, the dominant paradigm in the sociology of collective action presented the "masses" as incapable of rational deliberation and autonomous means-ends calculation. Over the last thirty years, that assumption has been turned completely upside down. Critical views came first from historians, who underlined the provision of norms and moral standards in explaining explosions of collective violence, yet the paradigmatic shift in the field was effected only with the reception of rational-choice approaches to human behaviour. With the establishment of a consensus on the strategic nature of agency, the rejected version is now available as a topic for more objective historical analysis.

Definitions of collective behaviour as irrational, spontaneous, and unreliable go back to Gabriel Tarde, Gustave Le Bon, and other social psychologists from the early twentieth century, who elaborated their 
works in the context of a crisis in classical liberalism which had given rise to fears about the emergence of mass politics. As part of a critical reappraisal of those authors, in the last few decades a new generation of social psychologists has reflected on the meanings and usages of terms such as

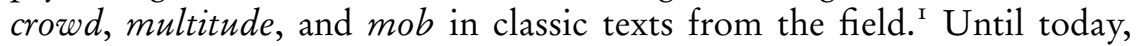
however, that interest in historical semantics has remained limited both in scope and range. Stereotypes and prejudices about multitudes in action are usually regarded as a universal component of cultures, and specialized research tends to focus on the contributions by the founders of the sciences of social behaviour. ${ }^{2}$

The purpose of this article is to widen our knowledge about the category of multitude through a historical study of its conceptual formation. The process of the conceptualization of the term involved relevant transformations in its meaning before it was coined for a scientificacademic category. Some of those transformations took place as early as the Enlightenment, which appears as a fulcrum in the history of the semantic field of disorder. Focus on the eighteenth century entails an important reorientation in the scope of analysis too. Economics did not exist as an independent science before the mid-nineteenth century, ${ }^{3}$ which means that modern theoretical definitions of rationality cannot be taken as understood in the period being studied here. ${ }^{4}$

Scholars have linked the growth of a public sphere during the Enlightenment with the emergence of representations of the subject as if it were a rational self-interested individual. ${ }^{5}$ The diffusion of the notion of

I. Especially comprehensive and influential among this literature is Serge Moscovici, The Age of the Crowd: A Historical Treatise on Mass Psychology (New York, I985).

2. See for example P. Baehr, "The Masses in Weber's Political Sociology", Theory and Society, I9 (1990), pp. 242-265. Ahistorical approaches to mass behaviour can be found in Carl F. Graumann, "Crowd Mind and Behavior: Afterthoughts", in idem and Serge Moscovici (eds), Changing Conceptions of Crowd and Mind Behavior (New York, 1986), pp. 222-227. History is usually limited to political philosophers. See for instance J.S. McClelland, The Crowd and the Mob: From Plato to Canetti (London, 1989).

3. See Margater Schabas, The Natural Origins of Economics (Chicago, IL, 2005), p. 2, according to whom "economic theorists regarded the phenomena of their discourse as part of the same natural world studied by natural philosophers" well into the nineteenth century.

4. Economic thought was actually developing hand-in-hand with modern representations of the social, both of which evolved from the wider field of moral philosophy. See Mary Poovey, "The Liberal Civil Subject and the Social in Eighteenth-Century British Moral Philosophy", in Patrick Joyce (ed.), The Social in Question: New Bearings in History and the Social Sciences (London, 2002), pp. 44-62. See also Istvan Hont, "The Language of Sociability and Commerce: Samuel Pufendorf and the Theoretical Foundations of the 'Four-Stages' Society", in Anthony Pagdem (ed.), The Languages of Political Theory in Early Modern Europe (Cambridge, 1986), pp. $253^{-276 .}$

5. See among others Albert O. Hirschmann, The Passions and the Interests: Political Arguments for Capitalism before Its Triumph (Princeton, NJ, 1977), and Charles Taylor, Sources of the Self: The Making of Modern Identity (Cambridge, I989). 
interest functioned as a landmark in the modern distinction between rationality and irrationality, while yet another source of evolution towards this modern dichotomy were notions of the multitude as coined and refined around the revolts and popular upheavals occurring throughout the eighteenth century. The policies enacted in the wake of enlightened despotism unleashed popular disturbances which played out as "laboratories of language", where the need to cope with the social reactions triggered by institutional reforms demanded new classifications and understandings of conflict which fostered semantic innovations beyond available repertoires.

This article will focus on one particular eighteenth-century popular revolt, the "motin de Esquilache" [Esquilache riots] of i 766 . Traditionally interpreted as a combination of food riot and anti-despotic protest, the revolt exploded in the capital of the Spanish monarchy, Madrid, spreading through several towns both on the peninsula and in the Americas. Classical social historians reckoned it was the most widespread, prolonged, and potentially devastating eighteenth-century revolt in western Europe before $1789 .^{6}$ It was nevertheless defeated, so it failed to bring with it a comprehensive alternative framework of semantic referents. Compared with the French Revolution, experimentation with language in the case of Bourbon Spain would be much more constrained by the inherited stock of meanings, ${ }^{7}$ but in this case the investment in discourse for assessing this revolt was significant, given the challenge posed to legitimate order.

A study of the elaboration of a conceptual vocabulary about the social certainly falls within the discipline of intellectual history, but reaches beyond it too. The issues treated in this article are similarly relevant to renewing the field of social history. In recent decades, the so-called "linguistic turn" has challenged classical social history by highlighting the linguistic dimension of all social experience. ${ }^{8}$ Profiting from a growing consensus, the perspective followed by this text tries to supplement social history with historical semantics.

Conceptualization can be understood as a kind of social activity produced by linguistic devices through communication. ${ }^{9}$ Classical social

6. Pierre Vilar, "El 'motín de Esquilache' y las 'crisis del Antiguo Régimen'”, Revista de Occidente, I 36 (1963), pp. 199-247.

7. See Rolf Reichardt and Hans-Jürgen Lüsebrink (eds), Handbuch politisch-sozialer Grundbegriffe in Frankreich, I680-I820 (Munich, I992); François Furet and Mona Ozouf (eds), The French Revolution and the Creation of Modern Political Culture: The Transformation of Political Culture, $1789-1848$ (Oxford, I988).

8. See Miguel Ángel Cabrera, Post-Social History: An Introduction (London, 2005).

9. In the wake of the masterful works by Reinhart Koselleck, conceptual history has become a proper disciplinary field of its own. See, for example, Reinhart Koselleck, Futures Past: On the Semantics of Historical Time (New York, 2004), and idem, The Practice of Conceptual History: Timing History, Spacing Concepts (Stanford, CA, 2002). See also Javier Fernández Sebastián (ed.), Political Concepts and Time: Approaching Conceptual History (New York, forthcoming), 
history tended to regard intellectual processes as indices of social change, but concepts themselves can be considered factors of historical transformation which deeply affect social dynamics. Once instituted, they influence human agency by constraining agents in the meaning they can attribute to reality, to their actions, and to those of others. That is so largely because concepts condense different layers of time, so their use in communicative action calls forth cumulative experience and at the same time invokes foreseeable expectations. ${ }^{10}$ Modern concepts in particular contain a whole new temporality which breaks with the past as thelos and orients action towards the anticipation of the future.

Historical semantics can profit as well from other sources of inspiration, especially the "Cambridge School" of intellectual history, whose members have stressed the role of traditions of language and the relevance of context to the elaboration of discourse. ${ }^{\text {II }}$ Attention to these dimensions is important for understanding the interplay between the inherited stock of meanings, the reception and re-elaboration of new vocabularies, and semantic transformation.

Conceptual change takes place not only within political processes; it can be regarded itself as a political event. ${ }^{\mathrm{I}}$ In the case of terminology relating to conflicts, conceptualization has strong bearings on social classifications affecting the recognition and identity of collective actors. The acquisition of new meanings by riot and multitude after I 766 was part of the response to the challenge made by the populace to legitimate

and Melvin Richter, The History of Political and Social Concepts: A Critical Introduction (Oxford, 1995). Conceptual history's interest in social history goes back to the works of Reinhart Koselleck, "Social History and Conceptual History", and idem, "Concepts of Historical Time and Social History", in idem, The Practice of Conceptual History, pp. 20-37 and I I 5 -I 30 , respectively.

I०. See, on this, idem, “'Space of Experience' and 'Horizon of Expectation': Two Historical Categories", in idem, Futures Past, pp. $255^{-276 .}$

I I. See the works gathered in John G.A. Pocock, Politics, Language and Time: Essays on Political Thought and History (Chicago, IL, 1989), and in idem, Political Thought and History: Essays on Theory and Method (New York, 2009). See also Quentin Skinner, Visions of Politics, I, Regarding Method (Cambridge, 2002). On the affinities and differences between the Cambridge School of political discourse in context and German conceptual history, see Melvin Richter, "Reconstructing the History of Political Languages: Pocock, Skinner, and the Geschichtliche Grundbegriffe", History and Theory, 29 (1990), pp. 38-70. On German conceptual history within the wider linguistic turn, see Melvin Richter, "A German Version of the "Linguistic Turn': Reinhart Koselleck and the History of Political and Social Concepts", in Dario Castiglione and Iain Hampsher-Monk (eds), The History of Political Thought in National Context (Cambridge, 2001), pp. 58-79.

I2. See Jacques Guilhaumou, Discours et événement. L'histoire langagière des concepts (Besançon, 2006). On the relations between political and conceptual processes, see also James Farr, "Understanding Conceptual Change Politically", in Terence Ball, James Farr, and Russell L. Hanson (eds), Political Innovation and Conceptual Change (Cambridge, 1989), pp. 24-49. 
order; the usage of the new concepts in discourse of itself forced a sharp reorientation of state policies. But semantic change had another unaddressed political effect: it informed the official accounts which have been used since as sources for the study of the motin de Esquilache. A study of the conceptual framework of those narratives and documents can offer critical insights useful not only for renewing the interpretation of the riot discussed here in particular but also for rethinking the conventional definition of riots in general.

\section{A LEGACY OF LINKING RIOTS TO CONSPIRACIES}

Renaissance humanism established a dividing line in Western culture by providing a renewed discourse that devised an autonomous status for the political sphere. Throughout the early modern period, republican tropes reinterpreted from the classical ideal of citizenship were refined and diffused through disputes and arguments in favour of or against civic versions of humanism. A fully fledged tradition of language was thus created that supplied a basic vocabulary on conflict and political agency. ${ }^{{ }^{3}}$ Republicanism made extensive use of two extreme expressions of disorder: revolution and civil war. Originally very close in meaning in the legacy from antiquity, with the rise of centralized monarchies and the raison d'état the two terms experienced a process of differentiation, revolution becoming identified more with concrete situations of extreme political unrest resembling a world turned upside down. ${ }^{\mathrm{I}}$

From the very origins of the humanist movement, discourse dealing with episodes of political conflict incorporated a series of anthropological assumptions. The bases and the leadership of upheavals were regarded as composed by two very different social and moral constituencies: the "plebs", or the mob, were understood to be an amorphous collective of individuals of low social class, easily manipulated, and who, when exposed to fanaticism and roused in great numbers, tended naturally to resort to violence. Leaders, on the contrary, were usually considered individuals belonging to upper social ranks or privileged corporations and were seen as utterly evil characters, plainly conscious of their immoral

I 3. See the classic work by John G.A. Pocock, The Machiavellian Moment: Florentine Politics and the Atlantic Republican Tradition (Princeton, NJ, 1975). See also Maurizio Viroli, From Politics to Reason of State: The Acquisition and Transformation of the Language of Politics, I250-I600 (Cambridge, I992).

I4. See in general Reinhart Koselleck, "Historical Criteria of the Modern Concept of Revolution", in Futures Past, pp. 43-57. The term was in fact applied to phenomena that today we would regard as lower-level social conflicts, such as local, even regional, social upheavals, and which do not engender deep and long-lasting social and political change. See Franceso Benigno, Specchi della rivoluzione. Conflitto e identità politica nell'Europa moderna (Rome, 1999), and Karl Griewank, Il concetto di rivoluzione nell'età moderna. Origine e sviluppo (Florence, 1979). 
condition and so capable of managing their passions for plotting. ${ }^{\text {Is }}$ Such a complex approach made conspiracy a necessary ingredient in any assessment of social disorder: not only minor uprisings or revolutions but even chaotic civil wars were assumed to require the concourse of some kind of intellectual authority and more or less explicit leadership by individuals of higher status. That is what made revolts so potentially dangerous, but at the same time allowed for specialized curtailment and repression on the part of the authorities, who could show mercy to the mobs and focus on conspirators and leaders.

European principalities possessed particular political constitutions and legal frameworks, although languages and frames of reference varied according to contexts, not only over time but also in space. In general, the nurturing of vernacular political cultures was propelled by the reception of humanist tropes in a tradition of holistic images of the body politic. An organic political imagination stressed hierarchy and interdependence between the different parts of the body politic, while the order thus created acknowledged legitimacy in a recourse to violence under circumstances regulated by custom, thus fostering a language of political liberty and representation. ${ }^{16}$

The monarchy of the Habsburg dynasty distilled a singular combination of those features. At its core, the kingdom of Castile, the military expansion and centralization of the monarchy played against the leverage of territorial representative institutions. The complete absence of a Reformation movement and the pro-Catholicism of the Habsburg Empire encouraged a rhetoric of meta-political goals that would exert a lasting influence over the whole legitimation discourse and the institutional setting of the so-called Catholic monarchy. ${ }^{17}$ In this context, the reception of civic humanist

I 5. See Peter Campbell, "Conspiracy and Political Practice from the Ancien Régime to the French Revolution”, in Barry Coward and Susan Swann (eds), Conspiracies and Conspiracy Theory in Early Modern Europe, from the Waldensians to the French Revolution (Aldershot, 2004), pp. 197-212, and T.J. Mintner, The Ideology of Conspiracy in Renaissance Florence (Madison, WI, 2006). See also, for a general perspective, the essays in Carl F. Graumann and Serge Moscovici (eds), Changing Conceptions of Conspiracy (New York, 1987). The primacy of a moral approach was expressed in the explanation offered for the ephemeral character of explosions of disorder, ultimately pinned on the inconstant influence of evil over human affairs. I6. Modern reappraisals of that medieval and early modern constitutional language can be found in Ernest H. Kantorowicz, The King's Two Bodies: A Study in Medieval Political Theology (Princeton, NJ, 1957), and Antony Black, Guilds and Civil Society in European Political Thought from the Twelfth Century to the Present (London, 1984). On its connections with representative institutions and the culture of legitimate resort to violence, see Otto Brunner, Land and Lordship: Structures of Governance in Medieval Austria (Philadelphia, PA, 1992).

17. See J.A. Fernández-Santamaría, Natural Law, Constitutionalism, Reason of State, and War: Counter-Reformation Spanish Political Thought, I (New York, 2005). See also José María Iñurritegui, La gracia y la república. El lenguaje de la teología católica y el "Príncipe Cristiano" de Pedro de Ribadeneyra (Madrid, I998). 
rhetoric would be marked by regular manipulation of republican tropes on the part of official discourse. ${ }^{18}$

Although Castilian humanists quickly adopted the available terminology of conflict, its use does not seem to have followed the expected pattern. The "War of the Comuneros" or Comunidades of Castile - a widespread urban revolt against the imperial aspirations of Charles V - would be referred to in learned circles not as a revolution but as a civil war. ${ }^{19}$ Imperial expansion did not, for its part, enhance the former semantic field: already, during the colonization of the New World, recurrent power struggles and upheavals triggered by reforms regulating control over Indians were labelled in official and unofficial accounts as "guerras civiles" [civil wars];; intervention in confessional disputes in continental Europe helped in turn to naturalize the usage of "civil war" for defining conflicts involving non-Catholic minorities inside the empire. ${ }^{2 \mathrm{I}}$

Yet the link between riot and conspiracy was kept, if not stressed, and is well reflected in the conventional usage acquired by the term "motin". Originally restricted to manifestations of military insurrection, the recourse to mercenary troops and the strong links between local military power and propertied groups made "riot" the usual term for referring to protests which erupted from resistance to Spanish domination and which involved the resort to violence by the populace. ${ }^{22}$ It does not seem, however, to have

I8. Outside Castile, things were different because other territories within the Habsburg monarchy profited from constitutional frameworks and political cultures more akin to the emerging language of politics. On the kingdom of Aragon see Xavier Gil, "Republican Politics in Early Modern Spain: The Castilian and Catalano-Aragonese Traditions”, in M. van Gelderen and Q. Skinner (eds), Republicanism: A Shared European Heritage, I: Republicanism and Constitutionalism in Early Modern Europe (Cambridge, 2002), pp. 263-288.

19. In De motu Hispaniae [The Movement of Spain], written in Latin, bellum civile is the most frequently employed term to refer to the revolt of the Castilian cities against the king-emperor Charles; the title of this unpublished narrative spoke, however, of a sudden and morbid agitation in the body politic falling within the semantic field of revolution. See Juan de Maldonado, De motu Hispaniae (Madrid, I99I). On this mainly urban conflict, see Pablo Sánchez León, Absolutismo y comunidad. Los orígenes sociales de la guerra de los comuneros de Castilla (Madrid, 1998), and Aurelio Espinosa, The Empire of the Cities: Charles V, the Comunero Revolt and the Transformation of the Spanish System (Leiden, 2009).

20. See, among others, Pedro Cieza de León, Las guerras civiles peruanas [1553-1584], edited by Carmelo Sáenz de Santamaría (Madrid, 1985), and Bernardo de Torres, Crónica Agustina [1657] (Lima, 1974).

2I. Thus, civil war amounted to the opposite of holy war, identified for its part with just war. The term was applied to domestic conflicts, for example in dealing with the Muslim minority in Granada. See Ginés Pérez de Hita, Guerras civiles de Granada [1595] (Newark, NJ, 1982).

22. A proxy figure is provided by the data offered in Real Academia Española: Banco de datos (CORDE), Corpus diacrónico del español, available at http://www.rae.es, last accessed on 7 May 20II: of 426 references in I 37 historical texts from before 1766 , over 70 per cent refer to a combination of military and civil riot, over 80 per cent involved instigation by leaders, and over 50 per cent make explicit reference to a conspiracy. This pattern seems to have started in the 
provided enough semantic content by itself and was commonly reinforced by adding to it qualifying synonyms such as "rebelion" [rebellion] or "tumulto" [tumult].

The seventeenth-century Hispanic political culture saw no major evolutions in the semantic field of disorder. In other European principalities the synergies between constitutional crises and confessional disputes urged semantic distillations and evolutions. Instead, in the domains of the Catholic monarchy fiscal crises triggered by military drawbacks were not supplemented with religious conflicts, and constitutional matters affected only territories outside Castile, such as Catalonia, Naples, or Portugal. Once crushed, any "revolutions" breaking out in such regions could be discredited as disorderly events mainly expressing opposition to natural authority. Inside Castile, the stock of meaning was at first affected by the expansion of neo-stoicism, a current in political thought stressing obedience to authority as an expression of moral integrity and endurance in the face of the contingencies of political events. ${ }^{23}$ In an institutional setting that fostered court factionalism, the rise of personal rule focused political intrigues and popular protest on trying to curtail the ascendancy of "strongmen", or validos. ${ }^{24}$ Outside the court, widespread but localized social conflicts seem to have been well covered by the inherited repertoire of terms. ${ }^{25}$

By the beginning of the eighteenth century, the terminology available for publicists in the new Bourbon dynasty appears to have been characterized by a degree of semantic imprecision and interchangeability in conventional usage. In the Diccionario de la lengua castellana, published between 1726 and 1739 by the newly created Real Academia Española under Philip V (I700-I746), the term bullicio for example meant "contienda, alboroto, sedición o tumulto" [fight, turmoil, sedition, or tumult]; while alboroto could be taken to mean "tumulto, ruido, altercación,

Americas, where it lasted long after 1766. See José Andrés-Gallego, Doce revoluciones y algunas cosas más (Madrid, I992), especially pp. I05-1 38 and 21 I-226.

23. On the implications of neo-stoicism for deactivating a culture of liberty and conflict, see David Burchell, "The Disciplined Citizen: Thomas Hobbes, Neostoicism, and the Critique of Classical Citizenship", Australian Journal of Politics and History, 45 (1999), pp. 506-524. Particularly for its influence in Spain, see Henry Ettinghausen, Francisco de Quevedo and the Neostoic Movement (Oxford, 1972).

24. On the Habsburg tradition of validos, or favourites, and its critics, see Antonio Feros, Kingship and Favoritism in the Spain of Philip III, I598-I62I (New York, 2000).

25. Juan E. Gelabert, Castilla convulsa, I63I-I652 (Madrid, 200I). A major synthesis is given in Pablo Fernández Albaladejo, La crisis de la Monarquia (Madrid, 2009). The death of Charles II in 1700 was the only event that led to a major internal constitutional crisis and, due to the intervention of England, touched indirectly upon religious affairs; yet it was quickly subsumed within the category of dynastic conflict. See John A. Lynn, The Wars of Lowis XIV: 1667-I7I4 (London, 1999). 
alteración, pendencia entre personas con voces y estrépito" [tumult, noise, fight, alteration, struggle between people with loud voices and sounds]. In the same official dictionary, "motin" was defined as "tumulto, movimiento o levantamiento del pueblo" [tumult, movement, or upheaval by the people], whereas "tumulto" stood for "motin, alboroto, confusión popular" [riot, turmoil, popular confusion]. ${ }^{26}$ All these terms were included in the juridical category of "bullicios" [rackets] and "conmociones populares" [popular commotions] inherited from Habsburg legislation. ${ }^{27}$

\section{THE 1766 REVOLT AND THE LIMITS OF TRADITIONAL VOCABULARY}

However, other trends were developing at the same time. With the waning of the religious wars and the consolidation of absolutist monarchies, the reflection on conflict was deeply transformed all across Europe, and especially so after the events of I688 in England, when for the first time a "revolution" had not led to the violence which would, according to the repertoire of the humanists, have been expected from sudden and radical political shifts. ${ }^{28}$ Profiting from that, the term could subsequently make its way into depolitized public spheres as a metaphor for the speed and depth of change in social habits. ${ }^{29}$ In turn, that semantic twist epitomized the emergence of a new language of natural rights and selfinterested individuals, which became diffused through a discourse on wealth and knowledge as being spontaneously produced through communication and exchange. ${ }^{30}$

In Spain, those trends were revised from the late seventeenth century onward by a generation of natural and moral philosophers who succeeded

26. Diccionario de la lengua castellana [letters A and B] (Madrid, I726), pp. $7 \mathrm{I} 3$ and 172 , [letters H, I, J, K, L, M, and N] (Madrid, I734), p. 6i 8, and [letters S, T, V, X, Y, and Z] (Madrid, I739), p. 375. On this dictionary see Pedro Álvarez de Miranda, "Hacia una historia de los diccionario españoles en la Edad Moderna”, Bulletin Hispanique, 97 (1995), pp. I87-200.

27. According to Frank Davie's "Corpus del español", between I 500 and I 700 the frequency of usage of motin and tumulto was higher however ( 9.6 and 6.2 per million words respectively) than that of bullicio (6 per million words). See http://www.corpusdelespanol.org/x.asp. The corpus has been compiled from over roo million words.

28. Alternatively, the nascent Whig historiography began to label the period prior to $\mathrm{I} 688$ as a "civil war". See John G.A. Pocock, "The Fourth English Civil War: Dissolution, Desertion and Alternative Histories in the Glorious Revolution”, in Lois G. Schwoerer (ed.), The Revolution of I688-1689: Changing Perspectives (Cambridge, I992), pp. 52-64.

29. See Koselleck, "Historical Criteria".

30. See Pocock, Machiavellian Moment; and David Wootton, Republicanism, Liberty, and Commercial Society, $1649-1776$ (Stanford, CA, 1994). A general overview of the political philosophical effects of these changes is offered by J.G.A. Pocock, "The Ideal of Citizenship since Classical Times", in Gershon Shafir (ed.), The Citizenship Debates (Minneapolis, MN, I992), pp. $3^{\mathrm{I}-42 .}$ 
in outflanking traditional neo-scholastic knowledge. ${ }^{3 \mathrm{I}}$ By the mid-eighteenth century a rapid and deeply rooted reception of other major semantic bases of commercial society had taken place, and this gathered momentum during the short reign of Ferdinand VI (I746-I759)..$^{32}$

As opposed to the language of civic virtue, that of interest as a source of wealth received enthusiastic recognition from the beginning not only among learned public figures and proyectistas [project-makers], but even from bureaucrats. With the accession to the throne of Ferdinand's brother Charles III (1759-1788), several policy measures were enacted on the basis of that inspiration, including intervention in public spaces of the capital with the purpose of emulating other major cities from other "civilized" nations. After reforming the organization of commercial exports, the monarchy essayed in I765 a new system of urban commercial supply that ended the traditional monopoly exerted by local authorities and opened the market to middlemen. ${ }^{33}$ The legislation was on the way to being implemented when, at the beginning of 1766 , a typical combination of bad harvests and supply shortages caused the price of bread to soar, creating an atmosphere of popular unrest. At just the same time, the favorito of the king, the Marquis of Squillace, banned the inhabitants of the capital from wearing the usual long capes and round hats, using the argument that they were inappropriate for a civilized population. He imposed instead new costumes of foreign origin. A context already ripe for connecting food shortages, market speculation, and reforms was thus driven to the verge of explosion by a measure that touched upon a tradition of popular criticism towards arbitrary personal rule.

On 23 March 1766 the populace of Madrid revolted. The uprising grew in extent and intensity, lasting for three whole days, and resurfacing in other major cities of the country. ${ }^{34}$ In a first move, quadrillas of commoners defied local authorities whenever they tried to force pedestrians to change their attire; they also attacked the house of the marquis and harassed other bureaucrats. The next day, as regular soldiers took to the

3. Jesús Pérez-Magallón, Construyendo la modernidad: la cultura española en el tiempo de los "novatores" (I675-I725) (Madrid, 2002).

32. See especially Pedro Álvarez de Miranda, Palabras e ideas. El léxico de la Ilustración temprana en España (I680-I760) (Madrid, I992). See also, inter alia, the studies by José Antonio Maravall, "La idea de felicidad en el programa de la Ilustración", and "El principio de utilidad como límite de la investigación científica en el pensamiento ilustrado", in idem (ed.), Estudios de historia del pensamiento español. Siglo XVIII (Madrid, 1999), pp. 233-268 and 669-684 respectively.

33. Concepción de Castro, El pan de Madrid: el abastecimiento de las ciudades españolas en el Antiguo Régimen (Madrid, 1987).

34. For a description see José Miguel López García, El motín contra Esquilache: crisis y protesta popular en el Madrid del siglo XVIII (Madrid, 2006), pp. 95-I29. On its seismic character, which reverberated even in the Americas, see José Andrés-Gallego, El motin de Esquilache, América y Europa (Madrid, 2003). 


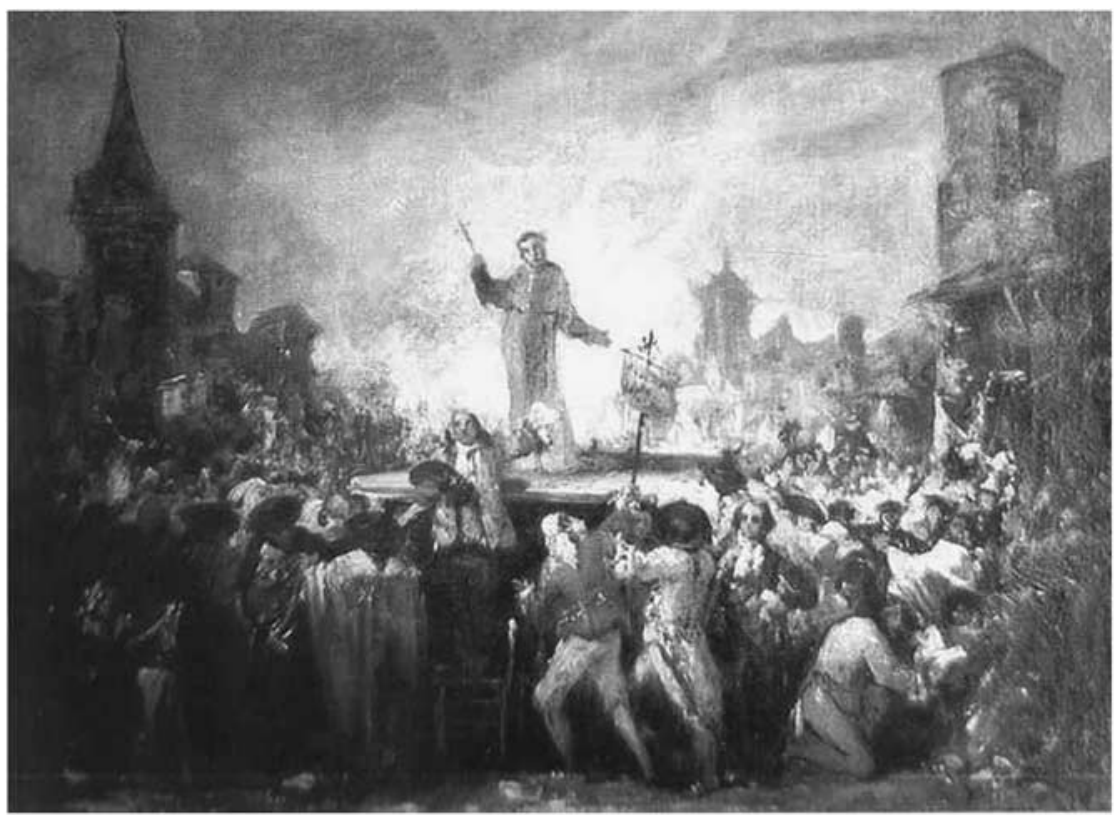

Figure I. "El motín de Esquilache" [Squillace riots] ( $1766-1767)$ ), by Francisco de Goya y Lucientes (1746-I828). The painting shows a Franciscan friar preaching the multitude in the second day of the riot against Squillace. It is supposed to represent Father Yecla, the monk who delivered the demands of the populace of Madrid to King Charles III. Priests were said to have emerged as spontaneous mediators between the rebels and the authorities, although this picture painted in the aftermath of the revolt stresses a perception of the populace as constituted by traditionalist religious values.

Oil on canvas, $46 \times 60 \mathrm{~cm}$, private collection. Used with permission.

streets, groups of men and women defied soldiers: scuffles with the royal guards produced over forty casualties from both sides. A crisis cabinet was summoned to court; the higher-ranking nobles and bureaucrats gathered around the king took the decision to comply with the people's demands, which included the removal of Squillace from office and the dismissal of the much-hated Belgian royal guards, as well as the repeal of the laws on grain markets and clothing.

Even so, as the king abandoned the city without fully enacting the concessions, groups of organized locals entered military garrisons, armed themselves, and blocked the entrances to the capital, sending an embassy to the royal palace in Aranjuez. Charles III replied that he would return to the city and enforce the agreements once the revolutionaries had handed over power to the legitimate authorities. Only after three days of popular control of the capital did the authorities manage to restore order, although there remained unrest for weeks in the form of libel and other anonymous writings. Other major cities of the peninsula experienced 
upheavals as well; they followed a similar pattern, with popular assaults on public granaries and the houses of merchants.

Among enlightened bureaucrats, such an unexpected and uncontrollable outburst of collective violence prompted the urgent desire to discredit it as part of the efforts to re-establish order. That in turn implied a need to name, qualify, and classify the events. The first occasion for so doing in the short term came in June 1766 , when a ceremony sponsored by the court was convoked for the purpose of asking the king to derogate the grants conceded to the populace. ${ }^{35}$ A royal decree, issued for the occasion by the attorneys of the Council of Castile, described the revolt at length.

Apart from declaring the illegitimacy of the so-called Congregación extraordinaria de gentes de Madrid [Extraordinary Gathering of the People of Madrid], the popular collective action of March was rejected as being "nula", "ilícita", "insólita", "defectuosa", "obscura", "violenta", "de pernicioso ejemplo", "obstinada", "ilegal", and "irreverente" [ineffective, illicit, unwonted, defective, obscure, violent, a dangerous model, obstinate, illegal, and irreverent]. The adjectives were explained in detail in order to justify the lack of recognition of the "congregacion" as a collective entity: thus, it was qualified as ineffective because it lacked any capacity to represent; it was considered illicit because it did not seek the recognition of the Cuerpo del Ayuntamiento [Body of the Municipality], "sin cuya participación previa no podia deliberar nada" [without the aid of which it could not take any decision]; it was qualified as unwonted because "jamás el Pueblo de Madrid se acostumbra a congregar en Cuerpo formado" [the People of Madrid never congregate as a Body]. Summarizing, the subject of the spring riot had been an "abominable congregación de gentes fantásticas $y$ discolas" [abominable congregation of fantastic and unruly people] that could not claim any recognition at all because, as the attorneys wrote, "sobre un Cuerpo quimérico e incierto no puede recaer representación constante y verdadera" [there can be no constant and true representation attributed to a chimerical and uncertain Body].

It can be seen that each of the arguments deployed against the subject of the revolt made use of the available stock of organological images rooted in inherited constitutional language. Much the same can be said about the terminology offered to name the events: bullicio and alboroto were recurrently employed, although tumulto was the most usual term. Interestingly enough, motin does not appear in this official document, although it was the term most used in the discussions by courtiers leading

35. Apart from representatives of the different judicial councils of the monarchy, there were others present, from intermediate bodies such as the Cuerpo de la Nobleza [Body of the Nobility] in the capital, the Ayuntamiento [Municipal Corporation] of Madrid, the Gremios Mayores y Menores [Higher and Lesser Guilds], and representatives of the clergy. See Jacinta Macías Delgado, Elmotin contra Esquilache a la luz de sus documentos (Madrid, I988), pp. 23 I-249. 
to the decision to instigate the ceremony. ${ }^{36}$ In spite of its vagueness and interchangeableness, the inherited terminology seems at first sight resilient enough to accommodate an episode of disorder much greater in intensity and extent than past experiences.

Yet official documents were not the only sources of discourse about the I766 revolt. A look at some of the others provides us with a different image of the semantic context created by the motin de Esquilache.

\section{SEMANTIC CRISIS: A RIOT WITHOUT CONSPIRACY}

Apart from "riot", terms with strong implications such as "civil war" and "revolution" were discarded too in the first official assessment of the events. Although their use had initially been much refracted in the Hispanic political culture, they could have had a second chance as classificatory categories in the aftermath of the 1766 revolt. As part of the revisionism of foreign political philosophy, a more orthodox interpretation of civic humanist tropes was being offered in those years, especially through the reception of Montesquieu. ${ }^{37}$ The new "strongman" at court, the Count of Aranda, himself sponsored a project full of republican overtones.

Actually, the summoning of the legitimate corporate bodies around the king reflected the rise of republican sensibilities in court circles in the aftermath of the revolt. It was not by chance that the declaration by the attorneys of the Council of Castile was preceded by a manifestation of loyalty signed up to by the nobility of the Villa y Corte. ${ }^{38}$ The gathering of a body of the privileged was part of a plan devised by Aranda for a reorganization of the aristocracy around a sort of mixed constitution in the humanist tradition, which would act as a bulwark against corruption and disorder.

This constitutional programme in the making demanded an interpretation of the riot inspired by civic tropes. It would not appear in

36. On this document see José Andrés-Gallego, "El problema de la representación popular en Aranda y su entorno (1766)", in José A. Ferrer Benimeli (ed.), El Conde de Aranda y su tiempo (Zaragoza, 2000), II, pp. 6II-620. Other revolts in provincial towns were referred to as "motines", but also non-distinctively as "tumultos populares" [popular disturbances], "algaradas", "asonadas", and "bullicios", all of them rather traditional synonymous terms. On the image of the rioters as a monstrous entity see Alberto Medina, Espejo de sombras. Sujeto $y$ multitud en la España del siglo XVIII (Madrid, 2009).

37. See Mario Onaindía, La construcción de la nación española. Republicanismo y nacionalismo en la Ilustración (Barcelona, 2002).

38. This was an institutional novelty, for since the late Middle Ages local corporations of the nobility had vanished from the urban political scene once municipal governments became monopolized by privileged families and offices became hereditary. See Pablo Sánchez León, "Changing Patterns of Urban Conflict in Late Medieval Castile", in Chris Dyer, Peter Coss, and Chris Wickham (eds), Rodney Hilton's Middle Ages: An Exploration of Historical Themes (Oxford, 2007), pp. 217-232. The last convocation of the nobiliar estate in the traditional parliament, or Cortes, took place in I 525 . 
official documents, but it was offered in other works sponsored by the new group in power. Tomás Sebastián y Latre, a member of the circle of the Count of Aranda, published an account of the revolt taking place in another major city of the Iberian peninsula, Zaragoza, capital of the old kingdom of Aragon, a region with experience of representative institutions. Republican language pervades the narrative, focused on the repression of the popular tumult rather than on the upheaval itself. ${ }^{39}$

The protagonists of the story are depicted as citizens in the ancient classical ideal successfully overcoming a situation of major social disruption. Neither civil war nor revolution are, however, used to define the events, and the author does not offer arguments for his avoiding both terms. That is all the more intriguing given that in his narrative the rioters of Zaragoza are characterized as embodying two of the features attributed in humanist literature to civil wars and revolutions: the low moral and social standards of the mobilized, and their recourse to violence when gathered in numbers in public spaces. Yet in excluding those terms Sebastián y Latre was perhaps adhering to a tradition.

For a third element was missing from the 1766 revolt, an element conventionally considered a sine qua non either of civil war or revolution: a conspiracy plotted by individuals from the upper ranks of society capable of manipulating the mob for their own immoral ambitions. In effect, an outstanding feature of the revolt against Squillace was the apparent absence of publicly declared or known leadership: the royal authorities did not detain any leader, and only a few priests were targeted, a move that led to an investigation which eventually ended with the expulsion of the Jesuit religious order from the domains of the Hispanic monarchy one year later, in 1767 . The Jesuits were accused of having incited the populace, but not of conspiring in the conventional sense of the term: from an organological perspective, a conspiracy implied machinations by individuals, not by an institution as a whole, because integral parts of the body politic could not conspire as such.

The formal absence of a conspiracy in the motin de Esquilache contradicts the fact that the revolt began after the imposition of a measure partly aimed at forestalling possible conspiracies. In effect, Squillace had justified the banning of traditional costume by arguing that it was

39. The author was assured that his book would inspire in his readers "las máximas de verdaderos Ciudadanos" [the principles of true citizens]. See Tomás Sebastián y Latre, Relación individual, y verídica del sucesso acontecido en la ciudad de Zaragoza, el dia 6 de Abril de I766, $y$ de todos sus demás progressos (Zaragoza, 1766), p. 3. Yet, instead of stressing liberty, the book underlines the duty of obedience and loyalty to the king and the law, a signal that this new reception of republicanism was also being refracted. A reappraisal of this text in the context of the Zaragoza revolt is offered in Fernando Baras Escolá, ¿Quiénes se amotinaron en Zaragoza en 1766 ? (Zaragoza, 1998). 


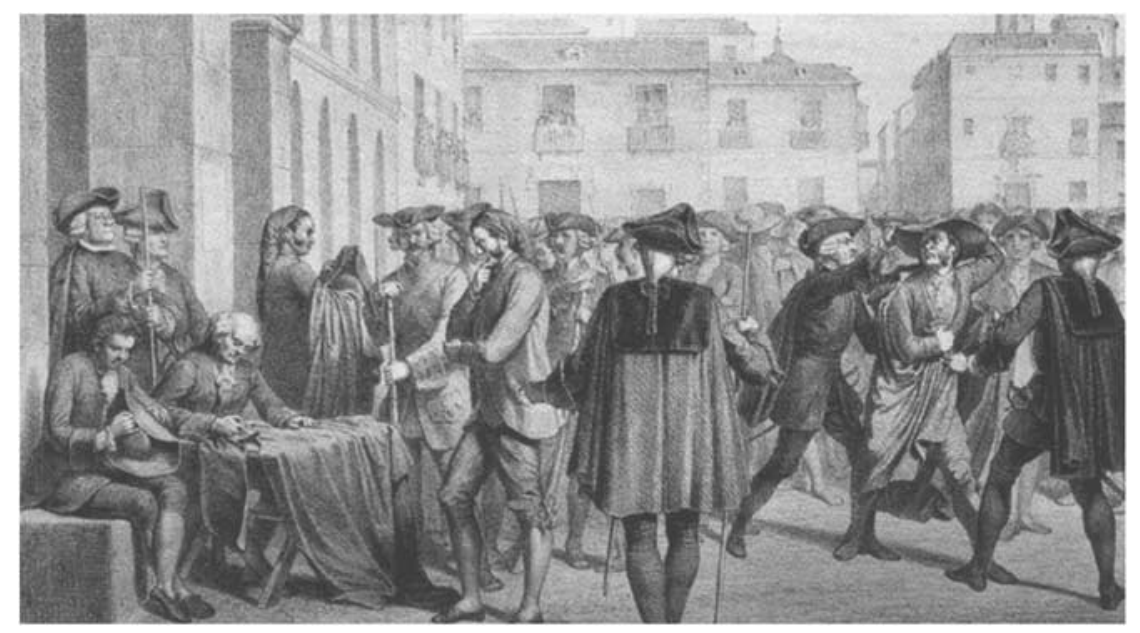

Figure 2. "Origen del motín contra Esquilache" [Origins of the riot against Squillace] (I 864), by Eusebio Zarza (fl.I842-I88I). Elaborated roo years after the events, the picture evokes an episode in the enforcement in 1766 of the legislation banning the inhabitants of Madrid from wearing traditional long capes and round hats. Part of a wider set of political measures oriented to adapt the capital to "civilization", the initiative implemented by local authorities triggered the riot against the favorito of King Charles III, the Marquis of Squillace. Although the revolt was caused by other deeper issues, this particular aspect was stressed in the Grand Narratives of nineteenth-century historiography, where it would be interpreted as a sign either of the love of liberty or traditional customs by the Spanish populace.

Lithography in two inks, $154 \times 240 \mathrm{~mm}$ in a sheet $(255 \times 360 \mathrm{~mm})$, printed in J. Donon's workshop.

inappropriate for standards of civilization, but also because long capes and hats allowed people to conceal their faces in public places. ${ }^{40}$ Once the revolt was over, the authorities declared their intention to detain those they assumed to have been the instigators; and yet it seems they failed to do so even after carrying out surveillance.

Over the decades, writers and scholars have addressed the question of whether there really was a conspiracy behind the 1766 revolt and, if so, who organized it. ${ }^{4 \mathrm{I}}$ However, contributions to the debate, which has involved both traditional political historians and classical social historians, have overlooked an important contextual element: since very early on,

40. Tomás y Latre, Relación individual.

4I. Some have affirmed the official dictum rejecting any relevant intervention by courtiers or members of the aristocracy; others have argued in favour of an aristocratic plot. See the summary in Andrés-Gallego, El motín, pp. 312-318, 569-593, and 647-663. Particularly noteworthy are those authors trying to probe the lack of involvement of Jesuit priests and denouncing the indictment of those priests as an opportunistic excuse for dismantling the institutional and cultural structure of the religious order as a prerequisite for subsequent educational reform. 
official discourse openly neglected the presence of any leadership in the revolt. In the document drawn up for the June I 766 ceremony, the general attorneys of the Council of Castile argued that the gathering of the populace of Madrid could not legitimately demand recognition "porque nadie aparece representando aquella especie de gentes" [because nobody appears to be representing that sort of people]. ${ }^{42}$

In spite of apparent efforts to identify a conspiracy, it seems that the authorities were unwilling to credit the rioters with leadership. In the past, however, no conflict seems to have called for such an approach, which suggests in the first place that the protest was regarded as a particularly strong challenge to the established order and called therefore for an especially tough discursive response, even at the cost of abandoning the long-established convention of linking riots to conspiracies. If leaders were acknowledged, protesters would gain some kind of recognition for their demands; more particularly, if an aristocratic plot were revealed, Aranda's constitutional project based on the moderating role of the nobility would be openly questioned before its implementation, adding a crisis of legitimacy from above to the one from below represented by the popular revolt.

Neglecting the intervention of a conspiracy was one way of denying political personality to individual protesters, irrespective of their social background. That was a course of action that fitted well in a context of absolutist rule, which implied the complete depoliticizing of subjects. Blaming the instigation of the riot on the Jesuit order reinforced the inherited organic language of social order: it was assumed that, by eliminating what had apparently turned out to be a rotten member, the body politic as a whole would revitalize itself.

The contextual needs of legitimization seem to have been satisfied with the legacy of semantic referents. The assessment of a revolt without a plot created, however, its own linguistic problem: in the absence of suitable terminology, the term used in referring to the revolt against Squillace depended on experimentation.

\section{CONCEPTUAL INNOVATION WITHIN INHERITED LANGUAGE}

In order to account for semantic experimentation in the aftermath of the March I 766 riot, we need to travel again, this time to Barcelona. The capital of the old principality of Catalonia witnessed no disorder, chiefly because the military governor had enough troops at hand to prevent it. ${ }^{43}$ Once order had been re-established everywhere, local authorities also 
associated themselves with the wave of expressions of loyalty to the monarch; in this case, Catalan writers had a chance to interpret events from a more distant position.

Francisco Romá y Rosell, attorney in the city audiencia [court], took this initiative. In 1767 , one year after the revolt, he published a work that was not just another pamphlet showing fidelity to King Charles III, but rather an entire Disertación histórico-politico-legal sobre los colegios y gremios de Barcelona [Historical-Political-Legal Dissertation on the Corporations and Guilds of Barcelona]. Most of the text was actually a justification for the privileges of the city's guilds, and of corporations in general, which he saw as a basic referent for identity in a well-ordered society, and one that played a moral role reaching beyond its particular constituencies. ${ }^{44}$

At first sight that had little to do with the issue at stake. Yet by arguing in favour of the social utility of corporations, Romá y Rosell's pamphlet focused on the role of guilds in situations of disruption to the social order. Corporations were a bulwark against disorder, but also the touchstone for their existence. In his view, revolts were the product of the malfunctioning of guilds, which resulted in an increasing inability to display their moral function over society as a whole. That perspective entailed a groundbreaking understanding of the sociological structure of the populace. For Romá y Rosell, the people did not exist as a separate, autonomous entity: they acquired personality only when duly incorporated and distributed among the different members that made up the body politic.

Such a radical version of organic discourse assumed a sociological distinction between good and evil subjects. In the humanist tradition no strong relationship could be established between the moral and the social bases of disorder: evil and passion were regarded as overall human temptations, the characteristic feature of the lower ranks being their potential exposure to both, and in large numbers, by manipulation from above. Instead, Romá y Rosell distinguished between a morally safe and reliable majority of members of corporations, and a minority of disenfranchized individuals who, excluded as they were from recognition and legitimate personality, easily became a threat to peace and order.

In fact, revolts were triggered whenever corporations failed to keep this marginal population under control. In his own words, if corporations and guilds were useful it was because "dan en todas partes pruebas de fidelidad cuando los vagos se amotinan" [they give proof of fidelity when the idle resort to mutinies]. ${ }^{45}$ Disorder necessarily started outside corporations.

44. What ultimately justified the existence of guilds was that through them "las buenas costumbres" [good habits] "trascienden hasta la infima clase de la sociedad" [reach the lowest classes in society]; Francisco Romá y Rosell, Disertación histórico-politico-legal sobre los colegios y gremios de Barcelona (Barcelona, 1767), p. 19.

45. Ibid., p. 29. 
While dignifying the lower ranks when duly incorporated into guilds or exposed to their moralizing effects, such rhetoric degraded rebels ultimately because of their lack of corporate affiliation. Thus, anticipating the qualification offered by the founders of the psychology of masses, Romá y Rosell referred to the unreliability of the masses, a view that was not so much a reflection of moral prejudice on his part but one based on sociologically elaborated reflection.

The multitude was being conceptually outlined as a social entity. Interestingly enough, Romá y Rosell did not make use of the usual terminology when referring to participants in violent collective action. Official documents and accounts of the 1766 events speak of "la Plebe más infame $y$ baxa" [the lowest and most infamous plebs]; ${ }^{46}$ instead of that he used the term "vagos" [idle], which, together with "ociosos" [lazy] and "malentretenidos" [of bad habits], was in that period acquiring the contours of a fully fledged semantic field. ${ }^{47}$ The classification he devised thus supplemented moral prejudice with the division of labour as a vehicle for social inclusion and exclusion.

Making distinctions among the multitude based on social and economic characteristics paved the way for a reclassification of manifestations of disorder. Innovatively, Romá y Rosell reduced the inherited variety of rather unspecific and interchangeable terms to just two alternatives: "conspiraciones" [conspiracies] and "motines" [riots]. ${ }^{48}$ The latter were the type of mobilization natural for the idle. Not only that: appealing in the first place to disenfranchized vagabonds, riots could also attract members from guilds. There was a social limit to that however. In Romá y Rosell's view, whereas the rank and file could be dragged into revolt, the heads of corporations resisted becoming involved in violent collective action against authority.

Such explicit exoneration of the representatives of corporations placed Romá y Rosell's argument on the same line as the official rhetoric of riot displayed in the capital and the court. Further elaboration was needed, though, in order to clarify why the lower and upper layers of corporations were prone to different behaviour in a context of social agitation. That is where the distinction between conspiracy and riot played a crucial role. What defined riots was not just the protagonism of the idle; it was the

46. Macías Delgado, Motín, p. I26, and Sebastián y Latre, Relación, p. 23. This terminology played with the formal resemblance between "infima" [lowest in rank] and "infame" [infamous].

47. By connecting disenfranchisement with idleness as the social basis of disorder, Romá y Rosell was positioning himself with the vanguard of political economists who, in those decades, were building the "myth of the idle mob". See Ellen M. Wood, Peasant-Citizen and Slave: The Foundations of Athenian Democracy (London, 1988). See also Fernando Díez, Utilidad, deseo y virtud. La formación de la idea moderna del trabajo (Barcelona, 200I).

48. See Romá y Rosell, Disertación, p. 29. 
singular character of its wider potential social bases. For Romá y Rosell, "por las más sólidas razones, y con la autoridad de la Historia" [according to the strongest of reasons and following the authority of History] it need be acknowledged that "los Plebeyos no tienen pensamientos, ni séquito para urdir conspiraciones" [plebeians have neither thoughts nor a retinue for plotting conspiracies]. ${ }^{49}$

Thus, Romá y Rosell was also founding the myth of the spontaneity of popular upheavals on sounder sociological ground: as opposed to the humanist tradition, for which the ephemeral character of revolts derived from the contingent display of evil in human affairs, collective action by the masses was now also seen as refracted by the social resources for mobilization at their disposal. He found the populace on the one hand unable to deploy the networks required for plotting conspiracies, that is, lacking enough material and social capital. That argument was, however, preceded by another, much more innovative and original one, according to which people of lower rank did not possess the intellectual status required for conspiracy. The sentence is rather ambiguous, though, and the lack of "pensamientos" can be understood in cognitive, educational, or moral terms; it probably involved a mixture of all three. ${ }^{50}$ In any case, that vision superseded the inherited tradition that denied personality to the masses exclusively due to their moral standards: what defined the multitude now was its inability to elaborate autonomously the ideas needed for sustained collective action.

In a context prior to the rise of economics and sociology as instituted sciences, Romá y Rosell was outlining the contours of the semantic field of irrationality. That involved conceptual definition, which he drew from the emerging language of the Enlightenment, which assumed culture and knowledge as conditions for the useful employment of human reason. The combination of that with tropes from political economy resulted in a sociological conceptualization of disorder: all that the populace could unleash were riots, "motines"; by contrast, conspiracies were taken as the natural type of disorder practised by the upper echelons because, even if it was for morally reprehensible purposes, their cultural level assured them the capacity for an independent use of reasoning.

In making his case for classifying the revolt against Squillace as a riot, Romá y Rosell was offering the authorities an understanding of the popular upheaval that lacked any significant ideological dimension. That was a way

\section{Ibid.}

50. See, among others, Gaspar Melchor de Jovellanos, "Introducción a un discurso sobre la economía civil y la instrucción pública", in idem, Escritos Económicos (Madrid, 2000), pp. 537-553. On the moral and cognitive dimension of education in the Spanish Enlightenment see José Antonio Maravall, "The Idea and Function of Education in Enlightenment Thought", in Wlad Godzich and Nicholas Spadaccini (eds), The Institutionalization of Literature in Spain (Minneapolis, MN, I987), pp. 39-99. 
of further depriving the revolt of legitimacy, and of reinforcing the official response to it. In order to do so, and to profit from the official denial of an aristocratic plot, he had to break discursively with the long-established tradition of including conspiracies as a sine qua non of relevant disorders. His alternative definition involved reflecting on the sources of unreliability, spontaneity, and irrationality. Even if he did not use the term multitud, the result was a definition which anticipated the scientific coinage of the concept 100 years later by the fathers of the behavioural sciences.

Conceptualization was part of the politics for restoring order after March I766. That helps explain why semantic innovation was pursued within a well-established legacy of organic tropes of order. The redefinition of motin actually profited from the ambiguity of the inherited terminology of disorder. According to the Dictionary of the Real Academia Española, whereas a tumult was a revolt against superior authority in general, a riot was defined as an upheaval by the people or a multitude "contra sus cabezas $o$ jefes" [against its heads or leaders]. Thus motin seemed better to suit Romá y Rosell's conceptualizing effort.

Nevertheless, his redefinition of the field of disorder involved a very distinctively modern ingredient: the incorporation of a new temporalization oriented towards the future. For Romá y Rosell, riots were to a certain degree legitimate processes of collective action. In his own words, as opposed to conspiracies, "los motines son consecuencia forzosa de los extremos de la libertad sin límites, y de la opresión del despotismo" [riots are the forcible consequence of the extremes of unlimited freedom and despotic oppression]. They could thus be anticipated and eventually avoided whenever order was "sujeto a una autoridad absoluta, pero moderada" [subject to an absolute, but moderate authority]. ${ }^{51}$

Far from justifying the revolt of March 1766 , the author was demanding the sort of government which would be capable of avoiding future disorders. That placed Romá y Rosell in line with the growth of a new science of government - centred on the notion of police - that tried to reduce the impact of Fortuna over human affairs by a modern understanding of necessity overcome through knowledge. ${ }^{52}$ Conceptualizations such as Romá y Rosell's were a prerequisite for those, since scientific discourse on politics could be elaborated only on the basis of concepts that incorporated a prognosis and anticipation of the future as a "horizon of expectations".

51. Romá y Rosell, Disertación, p. 267.

52. See Daniel Gordon, Citizens without Sovereignty: Equality and Sociability in French

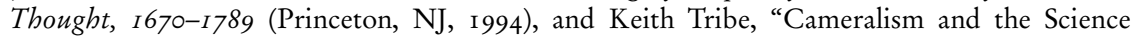
of Government", Journal of Modern History, 56 (1984), pp. 263-284. For the case of Spain see Pablo Sánchez León, "Ordenar la civilización: semántica del concepto de policía en la Ilustración española”, Política y Sociedad, 45:3 (2005), pp. 139-1 56. 
In the case of Bourbon Spain, the aftermath of the crisis of 1766 witnessed a reorientation in institutional reforms from the promotion of commerce to social control; interestingly enough, its core was a whole policy of repression towards individuals lacking corporate affiliation. ${ }^{53}$ If those measures could be successfully enacted it was in the first place because authorities could profit from a broader definition of riot as a mobilized aggregation of violent, disenfranchized individuals excluded from corporations. Defining and classifying revolt resulted in a major political event, deeply influencing the emerging institutional context after the motin de Esquilache.

\section{CONCLUSION}

In modern dictionaries, conspiracy and riot define rather opposite social phenomena; however, they had originally belonged to a common field by reference to which different instances of social disorder were named. Their semantic content became forever separated in the eighteenth century in the wake of popular revolts against Enlightenment reforms. The discourse surrounding the motin de Esquilache in Spain contains traces that allow for an interpretation of the way the process may have taken place in the context of the crisis of the Old Regime.

By depriving the masses of intellectual autonomy, Enlightenment discourse made a major contribution to the definition of modern dichotomies such as rationality/irrationality, multitude/minority, and publicity/secrecy. At the same time, it reconceptualized the social dimension of disorder, although that took place before the emergence of the social sciences, so that moral, cognitive, and social dimensions remained inseparable during the emergence of that conceptualization of the multitude.

From a wider perspective, the growing opposition between riot and conspiracy seems to have been part of a major transformation in learned culture, epitomized by the rise of critique as a socially embedded phenomenon. ${ }^{54}$ One of its longer-term effects would be the shaping of new kinds of prejudice, about multitudes in general and about the lower ranks

53. See Leopoldo Moscoso and Pablo Sánchez León, "Estado, reformas y revueltas: consideraciones sobre la quiebra del absolutismo en la península Ibérica (1759-1808)", in Esteban Sarasa and Elíseo Serrano (eds), Señorio y feudalismo en la Península Ibérica (ss. XII-XIX), (Zaragoza, I993), IV, pp. 423-446; and Leopoldo Moscoso, "Los límites de la profilaxis social en la Europa Ilustrada del Sur. Un estudio comparativo", Arqueología do Estado, I (I989), pp. $235-257$.

54. Koselleck's rewriting of the Enlightenment was based precisely on the argument that the growth of a public sphere in depoliticized absolute monarchies produced a trend towards secrecy and conspiracy in the social expressions of educated culture. See Reinhart Koselleck, Critique and Crisis: Enlightenment and the Pathogenesis of Modern Society (Cambridge, MA, I998). 
of society in particular, which were to reorient thoroughly the history of the semantic field of disorder.

The trends described in this article accelerated throughout Europe over the following decades. Police measures were partially successful in preventing and even curtailing riots, but they could not stop the expansion of another, ever more widespread phenomenon: the threats of conspiracy gathering momentum in the 1780 . ${ }^{55}$ As with so many other issues, the French Revolution represented a dividing line in the social usage of conspiracy, where it was seen alternatively as an integral component of revolution or as its utter negation, although both possibilities had something in common. Each stressed the new definition acquired by the modern phenomenon of revolution, in which purposive action played a major role.

That complex relationship between conspiracy and revolution was to be inherited by liberal elites, at the expense of the traditional link between conspiracy and riot. ${ }^{56}$ As the nineteenth century advanced, liberal discourse approached the repertoires of collective action used by those excluded from voting even more as reactive riots devoid of intellectual content regarding them. ${ }^{57}$ It was in this interpretive background that the classical social psychology of the masses was produced.

Yet if social scientists coined the conventional definition of riot, social historians were crucial to diffusing it in the twentieth century. By classifying historical revolts as riots, they actively helped to divulgate the identification of popular protests with the spontaneous eruption of the masses driven by necessity. In a less conscious way, a positivistic usage of available sources often made them assume the common meta-narrative inserted in them, according to which the populace lacked the capacity to produce political ideas independently.

Renewed by several generations of social scientists and historians, the rhetorical power of this meta-narrative has not only made invisible the

55. On the well-studied French case see particularly François Furet, Penser la Révolution Française (Paris, 1978); Lynn E. Hunt, Politics, Culture and Class in the French Revolution (Berkeley, CA [etc.], I984); Peter R. Campbell, "Perceptions of Conspiracy on the Eve of the French Revolution", in Peter R. Campbell, Thomas E. Kaiser, and Marisa Linton (eds), Conspiracy in the French Revolution (Manchester, 2007), pp. I5-32; and Timothy Tackett, "Conspiracy Obsession in a Time of Revolution: French Elites and the Origins of the Terror, 1789-1792", American Historical Review, ios (2000), pp. 691-71 3.

56. For the case of Spain see Juan Francisco Fuentes, "Motín", in Javier Fernández Sebastián and Juan Francisco Fuentes (eds), Diccionario politico y social del siglo XIX español (Madrid, 2002), pp. 466-468.

57. Studies on nineteenth-century Spain have only recently begun to unveil the ideological and political dimension of provincial and even rural revolts, which were discredited as simple "food riots" first by liberal elites and later by classical economic and social historians. See, for example, Guy Thompson, The Birth of Modern Politics in Spain: Democracy, Association and Revolution, I854-1875 (New York, 2010). 
semantic process reconstructed here, but also deformed modern accounts of relevant historical revolts. In the case of the protest against Squillace, there are pieces of evidence that have never been made to fit properly into conventional accounts of the events. For example, the fact that rebels produced important political documents such as a so-called "Constituciones u Ordenanzas" [Constitutions or Ordinances] signed by a self-identified "Cuerpo Patriótico en defensa del Rey y del reino para quitar y sacudir la opresión con que se intentaba arruinar estos grandes Dominios" [Patriotic Body in defence of the King and Kingdom in order to eliminate the oppression that was trying to ruin these great domains]..$^{5}$ Texts of that kind strongly suggest that 1766 was only partially a bread riot, or a protest against the decree banning traditional popular dress. It seems that there was in fact a discourse in the making which would reach beyond opposition to Enlightenment reforms.

It still remains to study the semantics of that discourse in detail, but also to assess the extent to which it was a product of popular communicative action, or a re-elaboration of other intellectual sources. ${ }^{59}$ Social history and the history of political language could establish a space for collaboration there. Until today, however, social and political historians have preferred to stick to debating whether there was an aristocratic conspiracy behind the revolt, a line of interpretation that implicitly reproduces old prejudices about the capacity of the multitude for producing independent discourse and deliberation.

In recent years, the concept of multitude has been returned from the historiography to the political philosophical arena. ${ }^{60}$ Its vindication as a legitimate collective agent of sovereignty in the globalized world has, however, been elaborated based on an interpretation of the classics of those who, like Baruch Spinoza, wrote before the semantic changes described in this article. Any chance of the concept of the multitude succeeding in the public sphere of the twenty-first century will require taking into consideration the cumulative effect of the layers of meaning incorporated since the eighteenth century into the conventional usage of the term, and in particular the deep effect that long-lasting prejudices have had on the inability of the masses to produce rational political deliberation.

58. Macías Delgado, Motín, p. 75. On this question see Pablo Fernández Albaladejo, Fragmentos de Monarquia (Madrid, I992), pp. 429-443.

59. The hypothesis of a tactical alliance between aristocratic networks resenting court policies and popular independent discontents has been posed by Giovanni Stiffoni, "Diplomazia ed 'opinione pubblica' veneziane di fronte ad una crisi dell'assolutismo riformatore: le rivolte di Madrid e provincie del I766”, Nuova Rivista Storica, 66 (1982), pp. 5 I I-546, 530.

60. See Michael Hardt and Antonio Negri, Multitude: War and Democracy in the Age of Empire (London, 2004). 